\title{
PROGRAM DERADISASI EKSTREMIS: PERSPEKTIF PERBANDINGAN
}

\author{
Lili Permadi \\ Sekolah Tinggi Ilmu Sosial Dan Ilmu Politik Al-washliyah \\ Email:_lili01@gmail.com
}

\begin{abstract}
Abstrak
Makalah ini menyajikan perspektif komparatif sampel program deradikalisasi di berbagai belahan dunia. Deradikalisasi dikonseptualisasikan sebagai penguraian "radikalisasi" - sebagai proses di mana individu melanjutkan dari keadaan pasif ke radikalisme melalui adopsi ideologi ekstremis sambil secara bertahap meningkatkan kemungkinan keterlibatan mereka dalam perilaku radikal kekerasan. Program yang ditinjau mencakup berbagai latar belakang politik, budaya dan agama dari negara-negara Skandinavia hingga benua Eropa, Timur Tengah, Asia Tenggara, serta Australia. Perhatian khusus diberikan pada proses deradikalisasi di penjara di seluruh dunia.

Kata kunci: Program Deradikalisasi, Radikalisasi
\end{abstract}

\begin{abstract}
This paper presents a comparative perspective on a sample of deradicalization programs in different parts of the world. Deradicalization is conceptualized as "radicalization" - as a process in which individuals proceed from a passive state to radicalism through adopting an extremist ideology while gradually increasing the likelihood of their involvement in violent radical behavior. The programs reviewed covered a wide range of political, cultural and religious backgrounds from Scandinavian countries to continental Europe, the Middle East, Southeast Asia, and Australia. Particular attention is paid to deradicalisation processes in prisons around the world.

Keywords: Deradicalization Program, Radicalization
\end{abstract}

\section{A. PENGANTAR}

Istilah "deradikalisasi" sering digunakan untuk mendeskripsikan proses dan hasil dari tindakan, kebijakan dan program aktual yang bertujuan untuk membalikkan atau setidaknya mengurangi efek "radikalisasi". 1Secara umum, "radikalisme" dapat diartikan sebagai "mengejar dan mendukung perubahan-perubahan yang berdampak jauh dalam masyarakat yang dapat membahayakan tatanan hukum demokrasi melalui

JURNAL PAPATUNG: Vol. 2 No. 1 Tahun 2019

ISSN: 2715-0186 
ancaman atau penggunaan kekerasan atau cara-cara tidak demokratis lainnya". 2 Derajat radikalisasi berbeda dari orang ke orang. Radikalisasi bisa jadi tanpa kekerasan dibatasi hanya dengan memegang ide-ide "radikal" lain bijaksana disebut sebagai 'radikalisasi kognitif'. Dalam pandangan manusia yang paling ekstrim, radikalisme dapat menyebabkan seseorang merasa perlu untuk mendukung bahkan berpartisipasi dalam tindakan kekerasan termasuk terorisme untuk mencapai tujuan yang diinginkan. McCauley dan Moskalenko menyebut yang pertama sebagai "radikalisasi opini" dan yang terakhir sebagai "radikalisasi aksi".

Pembalikan dari proses radikalisasi yaitu deradikalisasi adalah proses yang berusaha meyakinkan target program untuk melepaskan diri dari kekerasan atau mendukungnya seminimal mungkin atau jika memungkinkan, membimbing mereka untuk secara bertahap melepaskan dan menolak asumsi dan gagasan mendasar yang berkontribusi pada radikalisasi mereka. Oleh karena itu, tugas konselor dalam program deradikalisasi adalah pertama-tama mengidentifikasi atau "melepaskan" ide-ide radikal tertentu yang mengarah pada radikalisasi individu dan kemudian mengekspos kelemahan dalam logika subjek (atau interpretasinya terhadap teks-teks agama) dengan tujuan membimbing mereka untuk "mengesahkan" ideologi radikal mereka.

Mengurai efek dari proses radikalisasi juga membutuhkan perhatian yang diberikan pada dinamika aktual dalam kelompok radikal yang diidentifikasikan oleh individu. Menurut Bjørgo dan Horgan, kebijakan dan program pemerintah yang paling berguna yang ditujukan untuk deradikalisasi ekstremis adalah mereka yang mampu mengeksploitasi ketegangan di dalam kelompok-kelompok di mana individu radikal berada atau mengidentifikasi diri. Sementara pandangan konvensionalnya adalah bahwa "religius Teroris akan begitu tabah "bukti dari berbagai negara Muslim hingga saat ini menunjukkan hal yang sebaliknya menjadi kenyataan. Mengambil dari temuan mereka JURNAL PAPATUNG: Vol. 2 No. 1 Tahun 2019 ISSN: 2715-0186 
dari berbagai wawancara dengan anggota organisasi teroris di seluruh dunia, Horgan dan Bjørgo menulis, "Kami segera menyadari bahwa pelepasan dari teroris dan gerakan kekerasan lainnya pada kenyataannya adalah proses yang normal dan hampir konstan". Kebanyakan individu yang terlibat dalam terorisme "pada akhirnya melepaskan diri darinya dengan satu atau lain cara" dan beberapa gerakan teroris "bertahan lebih dari beberapa bulan, dalam kasus yang jarang terjadi bertahun-tahun, sebelum akhirnya berakhir".

Dalam kasus-kasus yang melibatkan salafi-jihadisme, upaya melawan radikalisasi ideologis terutama menargetkan interpretasi teologis dari teks-teks agama yang menghadirkan "konfrontasi yang ketat dengan rival politik" sebagai "metode yang secara ologis sah dan efisien secara instrumental untuk perubahan sosial". Menurut Ashour, deradikalisasi memiliki tiga dimensi utama: ideologis, perilaku, dan organisasional. Deradikalisasi ideologis melibatkan pembalikan ideologi radikal yang memerlukan delegitimasi metode bersenjata untuk mencapai tujuan politik dan penerimaan perubahan sosio-politik bertahap dalam konteks pluralis. Namun, Ashour memperingatkan bahwa deradikalisasi tidak mengharuskan seseorang menerima metode demokrasi. Yang terakhir adalah proses terpisah yang dapat kita sebut sebagai 'moderasi'. Kedua, 'deradikalisasi perilaku' dikatakan terjadi ketika individu atau kelompok radikal memilih untuk meninggalkan penggunaan kekerasan sebagai taktik tanpa harus mendelegitimasi dari sudut pandang ideologis. Terakhir, 'deradikalisasi organisasi' adalah ketika seluruh organisasi radikal mengabaikan penggunaan kekerasan, melucuti senjata, dan mendemobilisasi. Ketika proses berhasil di ketiga dimensi ini maka kami memiliki 'deradikalisasi komprehensif'.

Dalam lingkup prosesnya, upaya deradikalisasi dapat ditujukan kepada seluruh kelompok atau individu teroris atau radikal. Contoh kasus deradikalisasi kelompok JURNAL PAPATUNG: Vol. 2 No. 1 Tahun 2019 ISSN: 2715-0186 
dapat ditemukan di Libya (upaya deradikalisasi dan negosiasi antara pemerintah Libya dan Kelompok Pejuang Islam Libya, LIFG), Aljazair (dengan Islamic Salvation Army atau AIS, Armed Islamic Group atau GIA dan Group for Preaching) dan Combat atau GSPC), Mesir (dengan al-Gama'a al-Islamiyyah atau Kelompok Islam IG) atau Tajikistan (dengan Partai Renaisans Islam, IRP). Di sisi lain, Arab Saudi, Singapura, Australia, Yaman dan Indonesia termasuk negara-negara dengan program deradikalisasi yang utamanya berfokus pada pembalikan radikalisasi individu. Meskipun menyadari bahwa program deradikalisasi kelompok dan individu sama-sama signifikan dan memiliki beberapa aspek yang sama, paragraf berikutnya terutama didedikasikan untuk memeriksa isu-isu yang berkaitan dengan deradikalisasi di penjara dan karenanya lebih memperhatikan deradikalisasi radikalisasi individu atau terpidana teroris.

Deradikalisasi adalah fenomena yang kompleks. Menghilangkan efek pertemuan berbagai faktor radikal bukanlah tugas yang mudah oleh imajinasi mana pun. Hal ini semakin diperparah dengan tidak adanya dan kesulitan yang terlibat dalam mengembangkan metode yang valid dan andal untuk menilai efektivitas program deradikalisasi dalam jangka menengah dan panjang. Namun, mengidentifikasi aspek kunci dari masalah yang dihadapi yaitu radikalisasi adalah titik awal yang berguna ke arah yang benar. Radikalisasi adalah proses kompleks yang dihasilkan dari pertemuan berbagai faktor internal (pikiran dan perasaan) dan eksternal (fisik dan lingkungan ). Di antara faktor-faktor yang paling banyak disebutkan yang berkontribusi terhadap radikalisasi individu termasuk rasa ketidakadilan yang dirasakan (seringkali tanpa Ideologi yang dielaborasi sepenuhnya), ketidakamanan, ancaman (yang dirasakan atau nyata) kepada kelompok atau komunitasnya sendiri, kebutuhan akan makna atau "penjelasan yang jelas tentang apa sebenarnya dunia ini dan apa peran seseorang di dalamnya". Faktor lain termasuk ekstremisme ideologis, tekanan teman sebaya, JURNAL PAPATUNG: Vol. 2 No. 1 Tahun 2019 ISSN: 2715-0186 
pemimpin karismatik, kekerasan media, pelecehan anak, norma budaya, kekerasan struktural, peristiwa politik domestik dan internasional, represi pemerintah, simpati untuk yang "menjadi korban ', keingintahuan, pencarian kegembiraan, mencari teman atau komunitas, pencarian status atau identitas, dll. Ketersediaan ruang pengorganisasian dan akses ke senjata mematikan memberikan peluang bagi ide-ide radikal untuk diterjemahkan ke dalam aksi kekerasan.

Pengakuan fungsi sosial dan psikologis kelompok radikal penting dalam proses deradikalisasi. Tim rehabilitasi perlu memfasilitasi proses pelepasan pembelajaran sambil meminimalkan dampak psikologis dan sosialnya terhadap individu yang menjalani rehabilitasi. Misalnya, jika pencarian status dan identitas merupakan motivator utama bagi seseorang untuk bergabung dengan kelompok ekstremis, rasa hormat yang pantas perlu ditunjukkan kepada para narapidana selama dialog dengan religius dan konselor lainnya untuk menjaga rasa saling menghormati. antar pihak. Menyadari fakta ini, program rehabilitasi agama Yaman secara resmi mengembangkan apa yang mereka sebut "Etika Dialog". Sejalan dengan ini, para ulama yang menasihati narapidana ekstremis dan teroris di penjara Yaman diharuskan untuk menunjukkan rasa saling menghormati; menerima keserbaragaman dan komitmen terhadap etika perselisihan; memberikan narapidana kebebasan untuk mengekspresikan sudut pandang mereka; kesetaraan dalam berbicara menggunakan revisi dan referensi; hindari percakapan panjang dan interupsi yang membosankan; presentasi yang baik dengan menggunakan frase yang baik; mendengarkan dengan baik dan menghargai pendapat orang lain; pengendalian diri dan penghindaran reaksi negatif; menjadi sabar, jujur dan rendah hati; mempertimbangkan perasaan orang lain dan menghindari 'ironi'; dan Mengorganisir ide-ide sesuai dengan mata pelajaran yang akan dibahas. 
Penting juga untuk mengenali pengaruh ketidakberdayaan, pengucilan individu dan sosial, trauma dan penghinaan yang berkontribusi pada proses radikalisasi. dan mencoba untuk meyakinkan target mereka bahwa dunia ini menakutkan dan berbahaya, bahwa kekerasan secara ideologis (atau religius) dapat dibenarkan; bahwa kekerasan adalah satu-satunya cara yang efektif untuk menghadapi tantangan saat ini, yaitu tidak ada alternatif selain penggunaan kekerasan; dan bahwa kelangsungan hidup individu dan komunitasnya dipertaruhkan dan tindakan segera diperlukan. Selanjutnya, Konsekuensi dari melakukan kekerasan ilegal ditepis dan pelatihan disediakan bagi calon yang direkrut.

Penelitian telah menunjukkan bahwa dalam beberapa kasus peran faktor psikologis mungkin lebih besar daripada peran indoktrinasi agama atau ideologis. Bartlett dan Miller, misalnya, berpendapat bahwa adalah keliru untuk menganggap bahwa agama adalah penyebab utama kekerasan bahkan dalam kasus "terorisme yang tumbuh di dalam negeri" di Barat. Sebaliknya, mereka mencatat, faktor-faktor seperti tarikan emosional, pencarian karena kegembiraan dan kesejukan, tekanan teman sebaya dan status atau kredibilitas jalanan terkadang melebihi alasan agama. Mengikuti penelitian empiris mereka pada 68 radikal dan teroris, Bartlettt dan Miller menyimpulkan bahwa,... Terutama dalam kasus pemuda " tumbuh di rumah ", radikalisasi kekerasan belum tentu, atau seluruhnya, keputusan agama, intelektual, atau rasional. Ada tarikan emosional untuk radikalisasi. Untuk bergabung dalam pertempuran melawan kekuasaan dan otoritas negara-negara Barat dianggap berisiko, menggairahkan, heroik, dan memanfaatkan tradisi kontra-budaya dan anti-kemapanan yang dicontohkan oleh banyak subkultur pemuda, baik Muslim maupun non-Muslim. Lebih lanjut, tekanan teman dalam kelompok dan kode kehormatan internal dapat 
membuat kekerasan, dalam konteks sosial tertentu, menjadi jalan paling jelas untuk memperoleh status, rasa hormat, dan makna.

Demikian pula, Bjørgo dan Horgan mencatat bahwa geng pemuda cenderung memenuhi kebutuhan fungsional penting dengan memberikan identitas, komunitas dan kegembiraan dan bahwa ketidakmampuan untuk secara sengaja menggantikan fungsi tersebut dapat menyebabkan pemuda radikal gagal meninggalkan kelompok tersebut. Mencatat perkataan mantan anggota kelompok neo-jihadi Italia, Vidino menulis, “Riadh dengan sempurna merangkum ilema internal ini, menambahkan elemen psikologis:' Sulit untuk mengatakan pada diri sendiri bahwa kami berada di jalan yang salah. Dalam diri kita, juga dalam diriku, ada kebanggaan berdarah yang mencegah kita untuk mundur '". Dalam membuat konsep jalan bagi seseorang yang keluar dari pola pikir radikal, penting agar persepsi diri mereka tentang diri mereka dan apa yang mereka butuhkan jelas bagi konselor. Cara-cara variabel di mana pandangan agama ekstremis digabungkan dengan keadaan kehidupan nyata setiap individu yang memfasilitasi radikalisasinya menunjukkan kerumitan yang dihadapi tim rehabilitasi penjara ketika mereka mencoba membalikkan proses yang mendorong individu ke dalam lingkungan radikal di tempat pertama. Mencatat informasi yang diberikan oleh mantan pejuang neojihadi, Vidino menulis, Riadh menggunakan metafora untuk menjelaskan bagaimana kombinasi yang merusak dari kata-kata pengkhotbah karismatik dan keputusasaan target mereka bekerja: 'Ketika saya tinggal di Tunis suatu hari saya berhasil menangkap ikan seberat dua kilogram dengan tiang kecil. Bagaimana saya bisa memancing ikan sebesar itu dengan kail sekecil itu? Begitu sampai di rumah saya mengerti. Di perut ikan saya menemukan kail tua. Ikan itu mengambil umpan karena sudah tidak ada stamina yang tersisa untuk bertarung. Itu menjadi mangsa yang mudah ditangkap. Seperti kita, yang muncul di masjid tanpa pekerjaan, tanpa uang dan tanpa cinta, miskin secara JURNAL PAPATUNG: Vol. 2 No. 1 Tahun 2019 ISSN: 2715-0186 
spiritual dan dengan moralitas kita di bawah sepatu kita. Hanya butuh kail kecil untuk menangkap kami. "

Selain itu, persepsi persaingan antarkelompok (antar etnis, antaragama) dan kecenderungan umum mengenai kelompok sosial lain dengan permusuhan yang dibantu oleh harga diri rendah, serta keterampilan yang kurang berkembang di berbagai bidang seperti refleksi diri, empati dan manajemen konflik memberikan Lingkungan psiko-sosial yang memfasilitasi penyaluran ketidakpuasan dan frustrasi individu ke dalam partisipasi dalam gerakan radikal. Untuk membalikkan proses semacam itu, diperlukan pemahaman yang cermat tentang bagaimana setiap individu dipengaruhi oleh keadaan dan / atau dipengaruhi oleh berbagai agen radikalisasi. Dampak dari faktor individu (ekonomi, politik, psikologis, ideologis, dll.) Mungkin berbeda dari satu orang ke orang lain dan karenanya pendekatan standar yang terlalu menekankan hanya pada salah satu dari dimensi ini misalnya agama atau ideologis dapat memfasilitasi deradikalisasi beberapa tetapi tidak yang lain. Pendekatan yang dipersonalisasi dapat membantu menyesuaikan program deradikalisasi dengan kebutuhan spesifik setiap individu yang teradikalisasi berdasarkan keadaan uniknya. Di mana faktor ideologis dan agama memainkan peran yang kurang signifikan, masalah politik mungkin menonjol. Merefleksikan keefektifan program deradikalisasi yang disponsori pemerintah di Singapura, Kumar Ramakrishna menulis, Terlepas dari upaya terpuji ini, bagaimanapun, sisa pola pikir konspirasi masih menimpa elemen komunitas Muslim di Singapura... terlepas dari semua pekerjaan RRG yang benar-benar inovatif [Keagamaan Rehabilitation Group], kegelisahan umum yang mendasari komunitas Muslim Singapura - hasil dari keluhan beratnya dan kebencian kontemporernya terhadap kebijakan luar negeri AS dan sikap pro-AS pemerintah Singapura - tetap ada, membentuk sebuah 
amplop eksistensial yang membatasi di mana RRG kontra-ideologis pekerjaan harus beroperasi.

Pengamatan ini menunjukkan kemungkinan keterbatasan program deradikalisasi yang memfokuskan sebagian besar perhatian mereka pada pekerjaan kontra ideologis yang berhubungan dengan radikal individu dan / atau terpidana teroris dan pengalaman pribadi mereka. Program-program tersebut perlu dilengkapi dengan upaya-upaya yang ditujukan untuk menangani, sejauh memungkinkan, faktor-faktor kontekstual yang lebih luas yang mungkin secara langsung atau tidak langsung berkontribusi pada proses radikalisasi itu sendiri.

\section{B. PEMBAHASAN}

\section{Melibatkan Komunitas}

Agar upaya deradikalisasi berhasil di tingkat makro, diperlukan upaya untuk memperluas, dalam kata-kata Schneider, "radius of trust" di mana individu dan kelompok saling percaya. Schneider mencatat bahwa untuk berkembang, terutama sebagai masyarakat multikultural, radius kepercayaan harus diperluas melampaui komunitasnya sendiri untuk mencakup budaya, jenis kelamin, usia, dan kepercayaan yang berbeda. Beberapa studi kasus relevan sebagai model potensial dalam konteks ini. Yang pertama adalah program Norwegia yang dirancang untuk membangun kepercayaan di antara anggota komunitas, meningkatkan ketahanan dan menanamkan komunitas dari kecenderungan memecah belah. Proyek 'Keluar' di Norwegia didirikan pada tahun 1997 di mana otoritas pemerintah bekerja sama dengan masyarakat lokal. 'Keluar' terutama merupakan program pencegahan di mana badan-badan lokal (terutama pemerintah kota dan polisi) bekerja dengan komunitas lokal untuk mencapai tiga tujuan: membantu dan mendukung kaum muda yang ingin melepaskan diri dari JURNAL PAPATUNG: Vol. 2 No. 1 Tahun 2019 ISSN: 2715-0186 
kelompok rasis atau kekerasan lainnya; mendukung orang tua dengan anak-anak dalam kelompok rasis atau kekerasan; dan ketiga, mengembangkan dan menyebarkan pengetahuan dan metode ke profesi yang bekerja dengan pemuda yang terkait dengan kelompok kekerasan. Pekerja muda setempat, petugas kesejahteraan, guru dan petugas polisi bekerja secara langsung dengan pemuda untuk pertama-tama mengembangkan metode dan strategi untuk intervensi dan pencegahan dalam kaitannya dengan kelompok remaja yang melakukan kekerasan serta melatih praktisi dalam hal ini. Bjørgo, va n Donselaar dan Grunenberg mengamati bahwa dalam proyek-proyek seperti itu, kelompok jaringan orang tua terbukti sangat efektif bagi orang tua yang peduli untuk mengeluarkan anak-anak mereka dari kelompok ekstremis. Jaringan semacam itu juga dapat membantu upaya kontra-radikalisasi yang lebih luas dengan membantu membangun saluran komunikasi yang stabil di mana data empiris dari "pulse" kolektif komunitas dikumpulkan, diorganisir, dan dikumpulkan secara berkelanjutan. Informasi tersebut mungkin terbukti sangat diperlukan untuk mempertahankan model kontraterorisme yang adaptif secara dinamis.

Variasi yang berguna dari model ini adalah 'Social Cohesion Model' (SC) yang saat ini diterapkan di negara bagian Victoria di Australia. Model tersebut didasarkan pada prinsip-prinsip perpolisian masyarakat dalam lingkungan yang beragam dan multikultural. Inti dari keberhasilan model ini adalah membangun literasi budaya polisi. Beroperasi dalam lingkungan sosial yang beragam secara budaya dan bahasa, tuntutan untuk mengatasi hambatan budaya dan agama menjadi jelas. Komunikasi antar budaya, yang terkadang dipersulit oleh hambatan bahasa, menjadi tantangan bagi petugas yang terus berinteraksi dengan masyarakat. Membangun rasa saling percaya antara lembaga penegak hukum dan masyarakat adalah kunci keberhasilan pendekatan ini. Dengan demikian, Pickering, McCulloch dan Wright-Neville menunjukkan, pendekatan SC JURNAL PAPATUNG: Vol. 2 No. 1 Tahun 2019 ISSN: 2715-0186 
terhadap kontraterorisme "menggunakan undang-undang khusus yang spesifik, pasti untuk sementara dan sesuai dengan aturan hukum dan standar hak asasi manusia dan harapan dari pasukan polisi sipil".

Pelajaran yang berguna juga dapat diambil dari beberapa program deradikalisasi berbasis LSM di tingkat negara bagian dan nasional yang telah diujicobakan di Barat yang berfokus pada radikalisasi ideologis agama dan non-agama. Salah satu contoh organisasi non-pemerintah di Jerman yang melakukan program deradikalisasi untuk anggota kelompok sayap kanan ekstrim di negara tersebut EXIT-Deutschland.30 EXITDeutschland tidak membuat kontak awal lebih memilih untuk menyediakan dirinya melalui berbagai media dan mendorong mereka yang mungkin merasa membutuhkan layanannya untuk memulai kontak. Banyak dari individu yang mencari bantuannya adalah siswa putus sekolah atau perguruan tinggi yang mungkin menjadi mangsa propaganda ekstremis sayap kanan dan bergabung dengan berbagai kelompok semacam itu.

Program ini berfokus pada beberapa bidang utama. Pertama, membuat sketsa profil umum individu dan mencoba memahami pandangan dunianya, alasan yang memotivasi individu untuk mencari bantuan dari EXIT-Deutschland, tingkat tekadnya untuk merehabilitasi serta rencananya untuk masa depan. Pembuatan profil ini membantu para sukarelawan memahami area spesifik tempat mereka dapat membantu individu dalam perjalanannya keluar dari ekstremisme dan perilaku terkait. Kedua, relawan mencoba memahami situasi sosial ekonomi subjek. "Apakah putus sekolah itu punya tempat di mana dia bisa bekerja tanpa membahayakan keselamatannya? Atau apakah dia menerima tunjangan pemerintah? Apakah dia memiliki tempat tinggal yang memenuhi persyaratan keselamatan? Jika demikian, apakah agen tunjangan membayar sewa untuk tempat tinggal ini? ". Ketiga, para sukarelawan mencari cara untuk JURNAL PAPATUNG: Vol. 2 No. 1 Tahun 2019 ISSN: 2715-0186 
membangun jaringan sosial baru bagi individu yang direhabilitasi. Sebagai konsekuensi dari deradikalisasi dan meninggalkan mantan teman sebaya, individu tersebut harus membangun kembali jaringan sosial di luar kelompok sayap kanan yang ekstrim. Terakhir, program deradikalisasi berupaya membantu setiap masalah psikologis yang mungkin timbul sebagai akibat dari perubahan yang mungkin dialami individu. Biasanya durasi program bervariasi antara enam bulan hingga tiga tahun. Selain program yang dijalankan oleh EXIT-Deutschland, terdapat juga program deradikalisasi lainnya yang dijalankan oleh LSM maupun pihak berwenang Jerman yang memfokuskan perhatian mereka pada kelompok ekstremis sayap kanan di tingkat negara bagian dan federal.

Beberapa elemen program deradikalisasi yang memusatkan perhatian pada anggota kelompok ekstremis di komunitas yang lebih luas di Jerman dimiliki oleh beberapa program deradikalisasi yang relatif lebih mapan yang terutama ditujukan untuk deradikalisasi individu di antara tahanan Islam radikal dan / atau narapidana terorisme di bagian lain dari dunia. Namun, dalam beberapa situasi, profil umum dari para tahanan atau narapidana dapat menentukan beberapa modifikasi atau penyesuaian yang akan membantu untuk menyesuaikan program rehabilitasi dengan penerima yang dituju. Meski demikian, pengamatan secara umum menunjukkan bahwa program deradikalisasi yang ditujukan kepada terpidana atau terduga teroris dan radikal agama dapat memberikan kontribusi dalam upaya mengurangi ancaman terorisme di seluruh dunia. Meringkas pengamatan yang dilakukan terhadap keefektifan program deradikalisasi dan pelepasan di 15 negara di seluruh dunia, sebuah laporan oleh The International Center for the Study of Radicalization and Political Violence (ICSR) mencatat bahwa sementara perbedaan kontekstual menyulitkan untuk mengukur keberhasilan Hasil awal program deradikalisasi dan pelepasan individu menunjukkan JURNAL PAPATUNG: Vol. 2 No. 1 Tahun 2019 ISSN: 2715-0186 
bahwa mereka berdiri untuk meningkatkan efektivitas keseluruhan rezim kontraterorisme di masing-masing negara. Laporan tersebut mengidentifikasi pendorong utama dan prinsip pelepasan individu dan program deradikalisasi untuk memasukkan, Campuran dari berbagai jenis program, biasanya menggabungkan pendidikan ulang ideologis dan / atau agama dengan pelatihan kejuruan; Teman bicara yang kredibel, yang dapat memahami kebutuhan pribadi dan psikologis narapidana; Penekanan pada transisi narapidana kembali ke masyarakat arus utama, biasanya dengan memberi mereka sarana untuk memulai baru dan dengan membangun jaringan sosial yang jauh dari ekstremisme; dan Metode canggih untuk mengunci narapidana ke dalam berbagai komitmen dan kewajiban terhadap keluarga, komunitas, dan negara.

Namun, sementara sebagian besar ahli umumnya setuju dengan "pendorong" yang disebutkan di atas, orang mengamati bahwa dalam hal implementasi program aktual, beberapa negara lebih berhasil dalam menjalankan dan memasukkan berbagai prinsip ini dalam program aktual mereka daripada yang lain. Dengan demikian, tingkat keberhasilan program di berbagai negara bervariasi dengan menyoroti pentingnya perencanaan yang cermat, pelatihan relawan dan konselor yang tepat, mengadopsi pendekatan holistik dalam menangani masalah yang mendasarinya dan penilaian berkelanjutan dari program yang didorong oleh kebutuhan untuk meningkatkan praktik saat ini, beradaptasi dengan perubahan dan kebutuhan yang diamati.

Model lain yang berguna untuk memperluas upaya deradikalisasi dan kontraradikalisasi ke tingkat komunitas adalah Arab Saudi. "Program Konseling" Saudi menjalankan program rehabilitasi penjara bagi radikal jihadi dan teroris di negara tersebut. Komite penasihat program ini terdiri dari empat sub komite. Yaitu, Sub-komite Religius (menangani masalah-masalah teologis), Sub-komite Psikologis dan Sosial (terdiri dari psikolog, peneliti dan ilmuwan sosial atas nasihat ahli mereka), Sub-komite JURNAL PAPATUNG: Vol. 2 No. 1 Tahun 2019 ISSN: 2715-0186 
Keamanan dan sub-komite Media. Ini adalah pekerjaan Sub-komite Media yang paling relevan dengan diskusi ini. Subkomite Media membuat materi yang digunakan dalam program (untuk konseling tahanan dan narapidana). Ini juga menyediakan materi pendidikan untuk digunakan di sekolah dan masjid. Fokus Subkomite Media dari program deradikalisasi Saudi adalah penjangkauan dan pendidikan, terutama menargetkan pemuda Saudi. Ia melakukan penelitian ekstensif untuk mengidentifikasi cara terbaik untuk menjangkau kelompok sasarannya di masyarakat dan menggunakan media seperti internet, radio, televisi, dan cetak. Pesan 'Moderasi' dan kontra-radikalisasi disebarkan melalui berbagai media termasuk khutbah Jumat di masjid, ceramah dan lingkungan belajar. Sebuah pesan penting yang ingin disampaikan oleh Subkomite Media kepada anggota komunitas adalah bahwa "ekstremis hanya akan menggunakan Anda dan bahwa mereka yang terlibat dengan militan telah salah memahami ajaran dasar Islam". Subkomite juga memanfaatkan para jihadis yang direhabilitasi yang diberi konseling di penjara-penjara yang bersedia berbagi pengalaman mereka dengan memberi mereka waktu siaran di televisi untuk berkomunikasi langsung dengan publik Saudi tentang kejahatan radikalisme dan ekstremisme ideologis.

Oleh karena itu, selain pendekatan tingkat mikro seperti deradikalisasi individu terhadap narapidana dan teroris, program deradikalisasi perlu mengambil langkahlangkah yang diperlukan untuk mengurangi kemungkinan anggota keluarga radikal itu sendiri serta masyarakat luas menjadi radikal karena sitaan akibat dari penahanan atau penahanan pemenang roti mereka. Memperluas cakupan program deradikalisasi mungkin terbukti menjadi salah satu cara yang efektif untuk memperluas "radius of trust" antara otoritas dan komunitas terkait. Meskipun demikian, seseorang tidak boleh meremehkan pentingnya faktor ideologis dalam deradikalisasi. Sementara faktor kontekstual bertindak sebagai faktor eksternal yang beroperasi di tingkat lingkungan JURNAL PAPATUNG: Vol. 2 No. 1 Tahun 2019 ISSN: 2715-0186 
dan memengaruhi persepsi individu tentang dunia dan peran mereka di dalamnya, interpretasi religius dari peristiwa yang memengaruhi setiap individu dapat menentukan apa yang dia lakukan sebagai reaksi terhadap keadaannya. Seperti yang digambarkan dalam kasus Mesir, revisi teologi radikal awal oleh para pemimpin AlGama'a al-Islamiya dan fasilitasi interaksi mereka dengan pengikut mereka di penjara Mesir memainkan peran penting dalam deradikalisasi dan demobilisasi Al-Gama. 'a dan kelompok Jihad di Mesir. Tafsir radikal terhadap teks agama berperan penting dalam proses radikalisasi. Oleh karena itu, melawan interpretasi tersebut dengan pemahaman agama yang moderat dan lebih inklusif merupakan faktor penting dan berpotensi menentukan keberhasilan program rehabilitasi.

\section{Deradikalisasi di Penjara: Perspektif Komparatif}

Bersama dengan sekolah agama Islam atau madaris (madrasah tunggal) dan masjid yang dipimpin oleh para imam radikal, analis terorisme, terkadang dengan bukti empiris yang kurang meyakinkan, sering mengidentifikasi penjara sebagai sarang radikalisasi neo-jihadis. Dalam beberapa kasus, kekhawatiran akan potensi radikalisasi di Lapas / Rutan berdampak signifikan terhadap sifat, arah dan hasil program deradikalisasi di Lapas / Rutan tersebut. Misalnya, Omar Ashour mencatat komplikasi yang muncul dalam pelaksanaan program deradikalisasi di penjara Libya ketika pihak berwenang bertengkar tentang apakah akan mengizinkan anggota berpangkat lebih tinggi dari Kelompok Pejuang Islam Libya (LIFG) di penjara untuk bertemu dengan pangkat dan file untuk diskusi yang mungkin menyebabkan pelepasan mereka dan / atau akhirnya deradikalisasi. Kasus Libya menyoroti pentingnya memiliki pemahaman yang lebih baik tentang hubungan tahanan di antara narapidana radikal, pelaku teroris dan narapidana non-radikal yang menjalani hukuman. Apakah setiap individu akan diberi konseling sendiri atau apakah program deradikalisasi harus memungkinkan atau JURNAL PAPATUNG: Vol. 2 No. 1 Tahun 2019 ISSN: 2715-0186 
bahkan mendorong kegiatan kelompok atau diskusi yang diawasi di antara anggota kelompok adalah pertanyaan yang terkait erat dengan asumsi dasar seperti proses radikalisasi di penjara.

Di antara program rehabilitasi penjara teroris yang paling sering disebutkan adalah di Arab Saudi, Yaman, Singapura dan Mesir. Ada juga perhatian yang meningkat pada program rehabilitasi di penjara Indonesia untuk terpidana teroris. Dalam beberapa tahun terakhir, negara-negara Asia Tenggara telah menghadapi ancaman Islamisme radikal terutama dari kelompok Jemaah Islamiyyah (JI) yang berbasis di Indonesia yang berusaha untuk mendirikan kekhalifahan Islam di beberapa negara di wilayah tersebut. Pasca penangkapan beberapa tersangka teror di negara-negara seperti Singapura, Indonesia, Malaysia, dan Filipina, pemerintah di kawasan ASEAN telah berupaya untuk memperketat keamanan, meningkatkan upaya kontra-terorisme, dan meningkatkan pendekatan mereka dalam menangani ekstremisme ideologis dan agama. Di negaranegara seperti Singapura dan Malaysia, pengalaman yang diperoleh dari menangani pemberontakan Komunis selama pertengahan hingga akhir abad kedua puluh dan badan perundang-undangan yang ada yang berasal dari pengalaman tersebut memberikan titik awal yang berguna dalam menentukan pendekatan negara-negara ini dalam melawan ekstremisme radikal. Salah satu aspek terpenting dalam hal ini adalah penggunaan undang-undang seperti Internal Security Act (dicabut di Malaysia pada tahun 2011 dan diganti dengan undang-undang lain yang secara khusus ditujukan untuk ancaman keamanan) dengan asal-usul historisnya dalam perjuangan antara pemerintahan kolonial Inggris. dan pemberontakan Komunis di wilayah tersebut pada pertengahan hingga akhir abad kedua puluh. Intinya, ISA mengizinkan penahanan tanpa batas waktu tanpa pengadilan terhadap individu yang dianggap mengancam keamanan nasional. Di negara lain seperti Indonesia dan Thailand, kerangka hukum semacam itu tidak ada, JURNAL PAPATUNG: Vol. 2 No. 1 Tahun 2019 ISSN: 2715-0186 
sehingga pendekatan untuk menangani ekstremisme dan radikalisasi agama berbeda. Tinjauan komparatif meskipun terbatas terhadap pekerjaan rehabilitasi dalam beberapa kasus yang disebutkan di atas menawarkan beberapa wawasan komparatif yang berguna.

Pekerjaan Kelompok Rehabilitasi Keagamaan (RRG) di Singapura memusatkan perhatiannya pada perancangan dan penerapan program deradikalisasi bagi kelompok radikal Islam di fasilitas penahanan negara. Tidak seperti program deradikalisasi berbasis di Jerman yang disebutkan di atas di mana klien rehabilitasi sebagian besar adalah putus sekolah (atau individu sejenis), profil dari sebagian besar tahanan di Singapura menunjukkan bahwa "orang-orang ini bukanlah orang buangan yang bodoh, melarat atau dicabut haknya, dan dianggap normal. , pekerjaan terhormat ". Tingkat keahlian tinggi di antara Oleh karena itu konselor menjadi masalah yang sangat penting untuk meningkatkan efektivitas program. Konselor RRG biasanya bekerja dalam tim yang terdiri dari tiga orang yang terdiri dari pakar agama Islam, Psikolog, dan anggota Departemen Keamanan Internal Singapura (ISD). Selain keahlian di bidang teologi, relawan kiai juga mengikuti kursus diploma tujuh bulan di bidang konseling untuk menambah ketrampilan mereka. Tim RRG membimbing para tahanan secara individu dan menilai kemajuan mereka secara berkala. Mengikuti rekomendasi RRG dan pihak berwenang lain yang sesuai, beberapa tahanan telah dibebaskan dari penahanan dan tingkat residivisme sangat rendah, menunjukkan bahwa program yang dijalankan RRG cukup efektif dalam mencapai tujuannya. Namun, mengambil dari pengamatan di tempat lain di kawasan Asia Tenggara dan Indonesia pada khususnya, Ramakrishna berpendapat bahwa penggabungan mantan tahanan JI yang telah direformasi sebagai bagian dari tim rehabilitasi di Singapura akan menambah kredibilitas program dan juga efektivitasnya.

JURNAL PAPATUNG: Vol. 2 No. 1 Tahun 2019 ISSN: 2715-0186 
Mantan teroris atau mantan anggota tinggi organisasi teroris yang dihormati berfungsi sebagai penasihat dalam program deradikalisasi penjara yang disponsori pemerintah di beberapa negara di seluruh dunia terutama Arab Saudi, Indonesia dan Mesir. Ada kesadaran yang berkembang bahwa mengingat tingkat penghormatan yang tinggi bahwa komando "mantan teroris yang menyesal" tingkat tinggi ini di antara para pengikut mereka, mereka memiliki posisi yang baik untuk memainkan peran penting dalam mengurangi perekrutan baru ke dalam terorisme. Selain membantu tim rehabilitasi dengan pekerjaan kontra-ideologis di penjara, mantan anggota organisasi teroris juga dapat membantu pihak berwenang mengidentifikasi alasan yang memotivasi mereka untuk mengubah posisi ideologis mereka dan memutuskan untuk bekerja melawan mantan rekan mereka. dan dengan otoritas untuk melawan pandangan radikal. Refleksi oleh mantan anggota Jemaah Islamiyah, pembuat bom dan pelatih Nasir Abbas, "pembom bunuh diri gagal" Saudi Ahmad al-Shayea dan mantan anggota kelompok neojihadi Italia Buccinasco Pentiti dalam wawancara pasca penahanan mereka dengan pihak berwenang Italia terungkap dalam hal ini menganggap.

Deradikalisasi Nasir terutama karena kekecewaannya terhadap kepemimpinan JI dan ketidaksetujuannya terhadap JI yang menyerang warga sipil tak berdosa termasuk anak-anak atas nama "jihad". Selain itu, dia menunjukkan fakta bahwa perlakuan baik yang dia terima dari polisi Indonesia dan otoritas penjara setelah penangkapannya membuka mata yang membuatnya menyadari betapa menyesatkannya dia. Demikian pula, selama wawancara dengan penulis dan mantan jaksa penuntut Federal AS, Ken Ballen, mantan militan Saudi Ahmad Al-Shayear, mengingat bagaimana perlakuan baik yang dia terima dari staf keamanan dan medis Amerika selama penahanannya di Irak setelah penangkapannya berdampak besar pada perubahannya. posisi radikal sebelumnya terhadap Amerika Serikat. Al Shayea, seorang penyintas serangan bunuh JURNAL PAPATUNG: Vol. 2 No. 1 Tahun 2019 ISSN: 2715-0186 
diri yang ditipu untuk melakukan tindakan oleh operasi alQaeda di Irak tanpa sepengetahuannya, menjelaskan bahwa dia terkejut melihat bagaimana orang-orang yang dianggap sebagai 'orang Amerika jahat' ini sangat baik padanya saat mereka merawat lukanya. Dia mencatat bahwa pengalaman seperti itu menyebabkan kekecewaannya terhadap al-Qaidah dan ideologi mereka yang menyesatkan. Merekam kata-kata Ahmad Al-Shayea selama wawancaranya dengan mantan radikal, Ballen menulis:

Tiga hari setelah keamanan Irak memulai interogasinya, orang Amerika tiba... Ahmad, yang dipenuhi luka bakar dan hampir tidak bisa berjalan, tertegun. Cara hatihati orang Amerika membantu membawanya menuruni tangga menuju jip Angkatan Darat AS yang menunggu tidak lain adalah keajaiban lain [selamat dari pemboman bunuh diri menjadi yang pertama]. Salah satu perwira Amerika bahkan berbicara dalam bahasa Arab ... Orang-orang Ame mengatakan kepadanya, 'Jangan khawatir, semuanya baik-baik saja'.... Para ad Ahmadi sekarang tahu bahwa orang Amerika yang dia datangi ke Irak untuk dibunuh telah menyelamatkan hidupnya. Dan orang-orang Irak yang menjadi tujuan perebutannya telah mencoba membunuhnya seperti anjing... Abu Ghraib yang menyiksa orang lain menyelamatkannya. Dia diperlakukan dengan hormat... dengan kebaikan. Al Qaeda-lah yang 'menggunakan saya seperti alat. Aku adalah sepotong umpan busuk untuk memancing seekor dhub keluar dari lubang keringnya '.

Al-Shayea sekarang tampil di televisi dan melakukan wawancara dengan peneliti dan jurnalis membantu pemerintah Saudi dan program deradikalisasi negara untuk menyebarkan pesan moderasi dan mengungkap kelemahan ideologi radikal Al-Qaeda. Dengan sedikit pengetahuan tentang teologi Islam, Ahmad, seorang putus sekolah yang tegang hubungan dengan ayahnya dibujuk untuk melakukan perjalanan ke Irak oleh JURNAL PAPATUNG: Vol. 2 No. 1 Tahun 2019 ISSN: 2715-0186 
sepupunya setelah diperlihatkan gambar penyiksaan tahanan di penjara Abu Ghraib di Irak. Misinya adalah balas dendam daripada fanatisme ideologis. Perlakuan baik yang dia terima dari orang Amerika di Abu Ghraib mengubah persepsi sebelumnya tentang musuhnya ke kepalanya. Sementara pendidikan ulang agama memiliki peran penting untuk dimainkan dalam upaya deradikalisasi neo-jihadis, kasus Al-Shayea menyoroti pentingnya memahami jalur radikalisasi individu untuk menyesuaikan pendekatan yang lebih efektif bagi individu yang menjalani rehabilitasi.

Dalam banyak kasus, Vidino mengamati, proses deradikalisasi atau pelepasan dimulai dengan 'pembukaan kognitif'. Dan "Persis seperti yang terjadi dalam proses radika lisasi, peristiwa traumatis dapat membuat seorang militan merefleksikan dan mengevaluasi kembali komitmennya terhadap organisasi radikal". Menuturkan wawancara pasca rilis yang diberikan oleh anggota grup Italia Buccinasco Pentiti, Vidino mencatat bagaimana seorang anggota grup tersebut kehilangan keyakinannya dengan rekan-rekan Jihadi-nya dan gerakan ketika mengamati kurangnya empati terhadapnya ketika terluka di medan pertempuran di Afghanistan. Di tengah ketidakpedulian sebagian besar militan lainnya di kamp, "hanya temannya Lotfi Maaoui, seorang Tunisia lainnya dari Milan, membantunya dengan membawanya ke rumah sakit. 'Ledakan itu', kata Lazhar, "merupakan kejutan bagi saya dan juga bagi L otfi. Kami memahami bahwa hal-hal jihad ini adalah omong kosong belaka ". Lo tfi, sambil menangis ketika mengatakan ini menambahkan: "setelah kita mengerti kita tidak lagi ingin menjadi martir". Insiden di Afghanistan anistan ini mewakili, seperti yang dikatakan oleh kaum radikal yang direformasi, sebuah "seruan untuk membangunkan" baginya. Dalam kasus lain, penemuan oleh seorang neo-jihad dari kelompok yang sama dengan Lazhar bahwa Imam yang sangat mereka hormati dan yang membuatnya bergabung dengan kelompok itu bahkan tidak dapat menulis bahasa Arab yang tepat membuatnya menyadari betapa JURNAL PAPATUNG: Vol. 2 No. 1 Tahun 2019 ISSN: 2715-0186 
mudahnya dia dibodohi untuk bergabung. gerakan yang membuatnya memutuskan untuk meninggalkan grup. Kisah nyata yang begitu kuat tidak menggambarkan hanya kurangnya pengetahuan agama oleh sebagian besar kelompok radikal dan teroris, tetapi juga pola penipuan yang sering terulang dalam pertukaran sehari-hari antara anggota kelompok ini dan antara anggota berpangkat rendah dan pemimpin mereka. Cerita dan pengalaman seperti inilah yang membuat para mantan "jihadis" menjadi agen deradikalisasi yang efektif ketika berbagi pengalaman dengan radikal lain baik di penjara, di komunitas, atau di dunia maya.

Selain upaya yang ditujukan untuk melibatkan para teroris di penjara dan pusat penahanan dengan diskusi tentang kelemahan interpretasi ideologi dan agama radikal, negara-negara seperti Singapura dan Arab Saudi telah secara efektif dimasukkan dalam ketentuan program deradikalisasi yang memiliki sumber daya yang baik untuk dukungan keuangan bagi anggota keluarga yang membutuhkan. para tahanan serta menanggung biaya sekolah untuk siswa mereka selama orang tua mereka pergi. Meskipun sulit untuk diukur, dampak dari tindakan tersebut terhadap keberhasilan program secara keseluruhan tidak dapat diremehkan. Pihak berwenang di negara-negara ini percaya bahwa jika keluarga seperti itu dibiarkan sendiri tanpa pencari nafkah, organisasi radikal dapat turun tangan untuk mengisi kekosongan dengan bantuan keuangan yang dapat berkontribusi pada radikalisasi pasangan, anak dan kerabat mereka. Arab Saudi secara khusus memberikan perhatian khusus tidak hanya pada bagaimana program deradikalisasi dapat membantu keluarga tahanan atau narapidana secara finansial, tetapi juga bagaimana anggota keluarga tersebut dapat dilibatkan dalam program itu sendiri untuk memfasilitasi deradikalisasi orang yang mereka cintai selama di penjara sebagai serta setelah pembebasan mereka. 
Memang telah terdokumentasi dengan baik bahwa salah satu metode yang digunakan oleh kelompok radikal untuk menjamin kesetiaan dan di antara anggota kelompok serta menjaga kerahasiaan dalam kegiatan kelompok adalah dengan kawin silang anggota kelompok dengan kerabat anggota lain dari organisasi yang sama. Jadi, meskipun beberapa anggota laki-laki dari jaringan keluarga ini mungkin yang paling terlihat di mata pihak berwenang karena keterlibatan mereka dalam kegiatan kekerasan, seluruh jaringan keluarga termasuk anggota yang tampaknya pasif cenderung menjadi radikal. Yang terakhir memberikan dukungan logistik dan bentuk lain untuk seluruh kelompok dalam operasinya. Kelompok Jemaah Islamiyah (JI) yang berbasis di Indonesia di Asia Tenggara dan kelompok Al Qaeda di Semenanjung Arab (AQAP) yang berbasis di Yaman sangat dikenal karena telah melakukan praktik ini. Menurut Page, Challita dan Harris, di Yaman perkawinan silang ini telah menciptakan semacam "masyarakat mujahidin" yang terdiri dari "saudara" yang sering menikah dengan saudara perempuan militan lain yang menciptakan apa yang disebut "kebohongan jihadi fami" di Yaman. Dalam situasi seperti ini ketika seluruh keluarga secara kognitif diradikalisasi, memfokuskan upaya rehabilitasi hanya kepada mereka yang ditangkap teroris atau radikal di penjara dan pusat penahanan tanpa melibatkan anggota keluarga dalam program dapat merugikan dalam jangka menengah hingga panjang, terutama selama fase pasca pembebasan. ketika pengaruh dari anggota keluarga yang teradikalisasi dapat berkontribusi pada residivisme oleh lulusan program.

Konsekuensi potensial dari mengabaikan anggota keluarga dan kerabat narapidana radikal dalam proses rehabilitasi dapat diilustrasikan dengan tingginya tingkat residivisme di Yaman. Tiga tahun setelah kerja rintisan Hakim Hamoud al-Hitar untuk mendirikan program "Dialog ologis" pada tahun 2002, tingkat residivisme yang tinggi mendorong pemerintah Yaman untuk membatalkan program tersebut pada tahun JURNAL PAPATUNG: Vol. 2 No. 1 Tahun 2019 ISSN: 2715-0186 
2005. Pada tahun 2009, sekitar 200 orang radikal yang dibebaskan tahanan telah ditangkap kembali. Sementara beberapa narapidana hanya menggunakan dialog sebagai sarana untuk keluar dari penjara, seseorang dapat mengesampingkan peran anggota radikal dari apa yang disebut "keluarga jihad" dalam mengindoktrinasi kembali narapidana "rehabilita ted" yang bergabung kembali dengan keluarga mereka. Dimasukkannya konseling keluarga dalam program deradikalisasi Arab Saudi dan Singapura berusaha untuk melawan atau setidaknya meminimalkan kemungkinan penyimpangan seperti itu yang dapat terbukti sangat merusak kesuksesan program secara keseluruhan. Selain itu, seperti disebutkan di atas, dalam upaya meminimalkan residivisme mantan tahanan, program deradikalisasi penjara Singapura dan Saudi juga melibatkan psikolog dalam tim rehabilitasi yang bekerja sama dengan perwakilan pemerintah dan ulama dalam konseling masing-masing tahanan dan narapidana. Di antara tugas-tugas lainnya, psikolog dan psikiater dalam tim memantau kemajuan para tahanan dan narapidana dan mencari "pertobatan" yang sok untuk menyingkirkan kemungkinan pembebasan dini.

\section{KESIMPULAN}

Program deradikalisasi untuk para radikal neo-jihadi yang dipenjara dan teroris lainnya adalah eksperimen yang cukup baru. Meskipun residivisme dan bentuk penyimpangan lainnya tidak diketahui, secara keseluruhan catatan di sebagian besar negara yang saat ini melaksanakan program tersebut cukup menjanjikan. Lebih penting lagi, meski masih hari-hari awal untuk membuat kesimpulan umum yang serius dari praktik saat ini, pendekatan alternatif untuk tidak melakukan apa pun untuk menangani dimensi kognitif radikalisasi narapidana tidak terlihat lebih baik menurut standar mana pun. Fungsi penahanan dan pemenjaraan sebagai bentuk "pelepasan paksa" dari para JURNAL PAPATUNG: Vol. 2 No. 1 Tahun 2019 ISSN: 2715-0186 
terpidana radikal dan teroris. Namun, seperti yang ditunjukkan Horgan, dalam banyak kasus pelepasan fisik tidak selalu menghasilkan perubahan atau pengurangan yang bersamaan dalam dukungan ideologis individu atau kontrol sosial dan psikologis yang diberikan ideologi tertentu pada individu. Pelepasan tidak selalu mengarah pada deradikalisasi atau sebaliknya. Mengingat sifat kompleks dari proses radikalisasi itu sendiri, potensi individu untuk gagal menemukan kehidupan alternatif dan jaringan sosial setelah dirilis ditambah dengan ketidakmampuan mantan teroris untuk mengatasi stigma sosial dan tekanan psikologis yang menyertai status barunya mungkin. berkontribusi pada residivisme. Dengan demikian, setiap upaya yang bertujuan membantu teroris yang ditahan untuk memikirkan kembali komitmen mereka terhadap radikalisme, mengidentifikasi cara-cara alternatif untuk mengejar perubahan damai dan mengintegrasikan mereka kembali ke arus utama pasti akan menjadi kontribusi positif bagi pengalaman korektifnya.

Selain itu, untuk memastikan keberhasilan jangka panjang program deradikalisasi di pusat korektif, upaya tersebut perlu dilengkapi dengan program yang kuat yang bertujuan untuk melawan ekstremisme kekerasan di tingkat keluarga, komunal dan sosial. Dari studi kasus yang ditinjau di atas, langkah-langkah ini dapat mencakup, misalnya, konseling pribadi, dialog antaragama atau teologis, 'perpolisian komunitas', diskusi publik tentang masalah lokal yang menjadi perhatian, dan (jika sesuai) regulasi kurikulum agama untuk memastikan bahwa isi ajaran agama di sekolah atau perguruan tinggi (negeri dan swasta) mempromosikan koeksistensi serta tidak melanggar atau mengabaikan prioritas keamanan nasional yang ditetapkan secara hukum. 


\section{DAFTAR PUSTAKA}

Abuza, Zachary. "Pendidikan dan Radikalisasi: Perekrutan Jemaah Islamiyah di Asia Tenggara." Dalam The Makingof a Terrorist: Recruitment, Training and Root Issues, diedit oleh James J.F. Forest. Westport, Connecticut dan London: Praeger Security International, 2006.

Rehabilitasi Tahanan Jemaah Islamiyah di Asia Tenggara: Penilaian Awal" Dalam Meninggalkan Terorisme: Pelepasan Secara Individual dan Kolektif diedit oleh Tore Bjørgo dan John Horgan, 193-211. London dan New York: Routledge, 2009.

Ashour, Omar. "Pasca-Jihadisme: Libya dan Transformasi Global Gerakan Islamis Bersenjata." Terorisme dan Kekerasan Politik 23, no. 3 (2011): 377-97.

Ballen, Ken. Terrorists in Love: Kisah Kehidupan Sejati dari Radikal Islam. New York, London, Sydney, Toronto, New Delhi: Pers Gratis, 2011.

Bartlett, Jamie, dan Carl Miller. "Tepi Kekerasan: Menuju Menceritakan Perbedaan antara Radikalisasi Kekerasan dan Non-Kekerasan." Terorisme dan Kekerasan Politik 24, no. 1 (2011): 1-21.

Bjørgo, Tore, Jaap van Donselaar, dan Sara Grunenbe rg. "Keluar dari Kelompok Ekstremis Sayap Kanan: Pelajaran dari Program Penanggulangan di Norwegia, Swedia dan Jerman" Dalam Meninggalkan Terorisme: Pelepasan Perseorangan dan Kolektif, diedit oleh Tore Bjørgo dan John Horgan, 135-51. Lo ndon dan New York: Routledge, 2009.

Bjørgo, Tore, dan John Horgan. "Pengantar." In Leaving Terrorism Behind: Individual and Collective Disengagement, diedit oleh Tore Bjørgo dan John Horgan. London dan New York: Routledge, 2009.

Meninggalkan Terorisme: Pelepasan Perseorangan dan Kolektif, Kekerasan Politik. London; New York: Routledge, 2009

Blanchard, Christopher M. "Sekolah Agama Islam, Madrasah: Latar Belakang." Dalam Congress Reaserach Service (CRS) Report for Congress, Order Code RS21654: The Library of Congress, 2004.

Boucek, Christopher. "Pendidikan Ulang dan Rehabilitasi Ekstremis di Arab Saudi." In Leaving Terrorism Behind: Individual and Collective Disengagement, diedit oleh Tore Bjørgo dan John Horgan, 212-23. Lo ndon dan New York: Routledge, 2009.

JURNAL PAPATUNG: Vol. 2 No. 1 Tahun 2019

ISSN: 2715-0186 
Boucek, Christopher, Shazadi Beg, dan John Horgan. "Membuka Debat Jihadi: Komite Dialog Yaman." In Leaving Terrorism Behind: Individual and Collective Disengagement diedit oleh Tore Bjørgo dan John Horgan, 181-92. London dan New York: Routledge, 2009.

Cronin, Audrey Kurth. "Bagaimana Kampanye Teroris Berakhir." In Leaving Terrorism Behind: Individual and Collective Disengagement, diedit oleh Tore Bjorgo dan John Horgan, 49-65. London dan New York: Routledge, 2009.

Elworthy, Scilla, dan Gabrielle Rifkind. Membuat Sejarah Terorisme. Inggris: Random House, 2007.

Emmers, Ralf. "Keamanan Komprehensif dan Ketahanan di Asia Tenggara: Pendekatan ASEAN terhadap Terorisme." The Pacific Review 22, no. 2 (2009): 159-77.

F. J. Buijs, F. Demant, dan A. Hamdy. Strijders Van Eigen Bodem: Radicale En Democratische Moslims di Nederland. Amsterdam: Amsterdam University Press, 2006.

Horgan, John. "Pelepasan Individu: Analisis Psikologis." In Leaving Terrorism Behind: Individual and Collective Disengagement, diedit oleh Tore Bjørgo dan John Horgan, 1729. Lon don dan New York: Routledge, 2009.

Ilardi, Gaetano Joe. "Prison Radicalisation - the Devil Is in the Detail." http://www.arts.monash.edu.au/radicalisation/conferences-and-events/conference-2010/-downloads/prison-radicalisation-gji.pdf.

Integrated Terrorism Assessment Center (ITAC). "Jihadisme Militan: Radikalisasi, Konversi, Perekrutan." Dalam Seri Tren Terorisme diedit oleh Pusat Studi Intelijen dan Keamanan Kanada - Sekolah Urusan Internasional Norman Petterson. Kanada: Universitas Carleton, 2006.

JURNAL PAPATUNG: Vol. 2 No. 1 Tahun 2019

ISSN: 2715-0186 